\title{
Beyond the stony veil: Reconstructing the Earth's earliest large animal traces via computed tomography X-ray imaging
}

\author{
Mike Meyer ${ }^{\mathrm{a}, *}$, Nick Polys ${ }^{\mathrm{b}}$, Humza Yaqoob ${ }^{\mathrm{c}, \mathrm{d}}$, Linda Hinnov ${ }^{\mathrm{d}, \mathrm{e}}$, Shuhai Xiao ${ }^{\mathrm{f}}$ \\ ${ }^{a}$ Geophysical Laboratory, Carnegie Institution of Science, 5251 Broad Branch Rd. NW, Washington, DC 20015, United States \\ ${ }^{\mathrm{b}}$ Department of Computer Science, Virginia Tech, 3030A Torgersen Hall, Blacksburg, VA 24060, United States \\ ' Ingenuity Project, Baltimore Polytechnic Institute, 1400 West Cold Spring Lane, Baltimore, MD 21209, United States \\ ${ }^{\mathrm{d}}$ Department of Earth and Planetary Sciences, Johns Hopkins University, 3200 San Martin Drive, Baltimore, MD 21218, United States \\ e Department of Atmospheric, Oceanic and Earth Sciences, George Mason University, 4400 University Avenue, Fairfax, VA 22030, United States \\ ${ }^{\mathrm{f}}$ Department of Geosciences, Virginia Tech, Blacksburg, VA 24061, United States
}

\section{A R T I C L E I N F O}

\section{Article history:}

Received 9 January 2017

Revised 9 May 2017

Accepted 22 May 2017

Available online 30 May 2017

\section{Keywords:}

Lamonte trevallis

Trace fossil

Ediacaran

South China

Bioturbation

\begin{abstract}
A B S T R A C T
Trace fossils are superb lines of evidence for examining the ancient biologic world because they offer an opportunity to infer behavioral ecology of organisms. However, traces can be difficult to parse from their matrix, which leads to the loss of important morphological and behavioral data. This is especially true for the earliest marine animal traces from the Ediacaran Period (635-541 Ma), which are usually small ( $<5 \mathrm{~mm}$ in diameter) and simple (mostly small horizontal trails and burrows), and are sometimes difficult to be distinguished from co-existing tubular body fossils. There is also evidence that the prevalence of microbial substrates in Ediacaran oceans may have influenced emerging trace makers in nonactualistic ways from a late Phanerozoic perspective (e.g., microbial mats may have facilitated a strong geochemical gradient across the sediment-water interface). Therefore, the discovery of the relatively large traces of Lamonte trevallis from the Ediacaran Shibantan Member of the Denying Formation ( 551-541 Ma) in the Yangtze Gorges area of South China provides a unique opportunity to study early bioturbators. These trace fossils are large enough and have sufficient compositional contrast (relative to the matrix) for in situ analysis via X-ray computed tomography (CT) and microcomputed tomography (microCT). Each analytical method has its own advantages and disadvantages. CT scans can image larger specimens, but cannot adequately resolve small features of interest. MicroCT scans can achieve higher resolution, but can only be used with small samples and may involve more post-processing than CT scans. As demonstrated in this study, X-ray CT and microCT in combination with other 3D imaging techniques and resources have the potential to resolve the 3D morphology of Ediacaran trace fossils. A new Volumetric Bioturbation Intensity (VBI) is also proposed, which quantifies whole rock bioturbation using 3D analysis of subsurface traces. Combined with the ability to examine trace fossils in situ, the VBI can enhance our view of ancient ecologies and life's enduring relationship with sediments.
\end{abstract}

(C) 2017 Elsevier B.V. All rights reserved.

\section{Introduction}

Trace fossils offer a unique insight into the behavior of prehistoric organisms during their lifetime by preserving their activities and behaviors as opposed to just the physical imprint of their bodies (Bertling, 2007; Budd and Jackson, 2016; Miller, 2007; Seilacher, 2007). However, depending on the trace maker, trace size, type of trace, density of traces, and sediment media, it can be challenging to isolate and examine a trace within its matrix (Bednarz and Mcllroy, 2009; Jensen et al., 2006; Malpas et al.,

\footnotetext{
* Corresponding author.

E-mail address: mike.meyer.geo@gmail.com (M. Meyer).
}

2005; Miller, 2007). Animal trace fossils from the Ediacaran Period (635-541 Ma) are often particularly difficult to examine due to their small size, their simplicity, and their tendency to be preserved on a single plane of preservation (Droser et al., 2005a; Jensen et al., 2005; Sappenfield et al., 2011). Additionally, simple animal traces from the Ediacaran Period are sometimes similar to tubular body fossils and their preservation in microbial substrates renders it difficult to distinguish Ediacaran body and trace fossils based on bedding plane observation alone (Droser et al., 1999, 2002; Jensen et al., 2006; Sappenfield et al., 2011; Tarhan et al., $2015,2013)$. Lamonte trevallis is a relatively large Ediacaran ichnospecies that is preserved differently than most trace fossils from the time period. Discovered in the Shibantan Member of the Deny- 
ing Formation ( 551-541 Ma) in the Yangtze Gorges area of South China, $L$. trevallis offers a unique opportunity to study early bioturbators (Chen et al., 2013a,b; Meyer et al., 2014b).

Lamonte trevallis is a millimeter-scale animal trace fossil associated with microbial mats. It includes three components: surface trackways, vertical traces, and horizontal tunnels. These three components are sometimes connected and they were likely made by the same bilaterian animal, representing locomotion (repichnia), resting (cubichnia/domichnia), and undermat mining behaviors (fodichnia), respectively. The horizontal burrows, relatively large for the time period (up to $\sim 1 \mathrm{~cm}$ in diameter) and preserved in full relief, are the most commonly encountered variant of $L$. trevallis morphology (Chen et al., 2013a,b). L. trevallis burrows occur exclusively within clayey and silty crinkled microlaminated layers that are interpreted as the remnants of amalgamated microbial mats (Chen et al., 2013a; Meyer et al., 2014b). These microbial mats were ubiquitous during the Ediacaran Period, often sealing the sediment from geochemical exchange with the overlying water column (Duda et al., 2014; Gingras et al., 2011; Tarhan et al., 2013; Zakrevskaya, 2014). The high bedding-plane bioturbation densities and close association of $L$. trevallis burrows with microbial mats implies that the burrowers were actively moving through the mats, possibly exploring them for oxygen and nutrient resources.

The behavior represented by these traces is often obscure, because the burrow networks frequently have a vertical component (taking them away from the exposed plane of preservation), and are thus hidden within the sediment. Hence, an analytical technique is needed to image the trace fossils in situ and in three dimensions within their matrix. Targeted petrographic thin sections were of limited utility in earlier $L$. trevallis studies due to their two-dimensional nature and limited coverage (figs. 3 and 4 in Meyer et al., 2014b). Serial grinding through a hand sample has been used before to examine trace fossils, but this can be time consuming and ultimately destroys the fossil material (Bednarz and McIlroy, 2009; Sutton et al., 2001). Magnetic resonance imaging (MRI) analysis has also been used to analyze trace fossils, but requires a sufficient amount of porosity that the carbonate matrix of $L$. trevallis lacks.

The use of X-ray computed tomography (CT) and microcomputed tomography (microcT) has been growing (Abel et al., 2012) and has proven to be useful for non-invasive examination of the interior of vertebrate fossils (Maisano et al., 2006) as well as some soft-bodied fossil material (Sutton et al., 2001); and more recently Ediacaran body fossils (Hagadorn et al., 2006; Schiffbauer et al., 2012; Meyer et al., 2014a; Wan et al., 2014). This analytical method has thus far been used only a few times to examine trace fossils (Meyer and Polys, 2015; Parry et al., 2015; Yaqoob et al., 2015), and the prospects for the field of ichnology are extremely promising. $L$. trevallis fossils are large enough and have sufficient compositional contrast (relative to the matrix) for CT and microCT analysis (Meyer and Polys, 2015; Yaqoob et al., 2015). Hence, using this novel fossil processing technique, this research addresses the following questions: (1) Can L. trevallis fossils be virtually extracted from their matrix? (2) Can the amount of bioturbation of the traces be quantified? and (3) What relationships did the L. trevallis trace makers have with the sediments?

\section{Geological setting}

The geological setting and stratigraphic framework of the Dengying Formation (Fig. 1) in the Yangtze Gorges was presented in detail by Chen et al. (2013a,b) and Meyer et al. (2014b). To summarize, the Dengying Formation overlies the early-middle Ediacaran Doushantuo Formation (635-551 Ma) and underlies early Cambrian Yanjiahe Formation (Dong et al., 2009; Jiang et al.,
2012). The Dengying Formation records the latest 10\% of the Ediacaran Period in South China, but it can have up to three times the thickness of the underlying Doushantuo Formation, which records the preceding 90\% (Jiang et al., 2011; Zhou et al., 2017). The Dengying Formation was deposited on a shallow water carbonate platform, and its age is constrained to 551-541 Ma (Condon et al., 2005; Jiang et al., 2009; Zhu et al., 2009). The Dengying Formation is divided into three units, in order of ascending age: the Hamajing, Shibantan, and Baimatuo members (Fig. 1B).

The samples analyzed in this work were collected from the Shibantan Member. This is the most fossiliferous member of the Dengying Formation and contains numerous body and trace fossils. Body fossils include Vendotaenia (Anderson et al., 2011), Paracharnia (Sun, 1986), Yangtziramulus (Shen et al., 2009; Xiao et al., 2005), Curviacus (Shen et al., 2017), Pteridinium and Rangea (Chen et al., 2014), as well as trace fossils such as Palaeophycus/Planolites, Helminthoidichnites, and Torrowangea (Weber et al., 2007; Zhao et al., 1988). The Shibantan Member at the collection site (Fig. 1C and D) is composed of dark gray, thin-bedded, bituminous limestone likely deposited in a shallow subtidal setting. Layers exhibiting cross stratification and rip-up clasts are rare but present, indicating that episodic high-energy events, such as storms, affected the depositional environment (examples of these can be see seen in fig. 2E and F of Meyer et al., 2014b). Crinkled microlaminae consisting of organic-rich, calcareous clays and silts are very common, and are often intercalated with thin limestone layers of intraclastic, pelloidal, and oolitic packstone and grainstone (Fig. 1B). These crinkled microlaminae are interpreted as microbial mats that trapped silts/clays and were subsequently cemented by diagenetic calcite (Chen et al., 2013a,b; Meyer et al., 2014b). The intraclastic limestone layers range from 0.5 to $20 \mathrm{~mm}$ thick, consisting of fine-grained $(\sim 50-100 \mu \mathrm{m})$ peloidal and oolitic packstone and grainstone. The microlaminated layers are $0.1-2 \mathrm{~mm}$ thick and contain more abundant clays and silts compared to the intraclastic limestone layers. Some clayey layers appear to be much thicker, but these are actually many, tightly packed clayey laminae (Fig. 1B). Lamonte trevallis fossils occur exclusively in the microlaminated layers.

\section{Methods and materials}

The analyzed hand samples, Lt1 and Lt2 (Fig. 2), were collected from a quarry near Wuhe in the Yangtze Gorges area (30 46 $51.61^{\prime \prime}$ $\mathrm{N}, 111^{\circ} 02^{\prime} 24.96^{\prime \prime} \mathrm{E}$ ) where the Shibantan Member is quarried as a raw material for construction purposes. The hand samples were collected as float from the top of the northern most quarry wall (Fig. 1D), $\sim 70 \mathrm{~m}$ above the base of the Shibantan Member. The hand samples were selected for their prominent Lamonte trevallis traces, which were partially exposed on their surfaces; and their sizes, which made them appropriate for use with the CT scanner. These trace fossils and associated hand samples have been deposited in the Virginia Polytechnic Institute and State University Geoscience Museum (VPIGM).

\subsection{MicroCT analysis of Lt1}

Lt1 (VPIGM-4696) was scanned via microCT (Figs. 3 and 4) using a Bruker SkyScan1173 at Micro Photonics in Allentown, PA, USA. Only part of the total hand sample was scanned (Fig. 2A-D). A Hamamatsu flat panel X-ray source operating at $130 \mathrm{kV}$ and $0.61 \mathrm{~mA}$ with no X-ray prefilter was employed. An empty container wedge was used. Slice thickness corresponds to one line in a CCD image intensifier imaging system, with a source-to-object distance of $251 \mathrm{~mm}$, resulting in $0.05 \mathrm{~mm}$ interslice spacing. For each $2240 \times 2240$ pixel slice, 1800 views were acquired with 10 sam- 


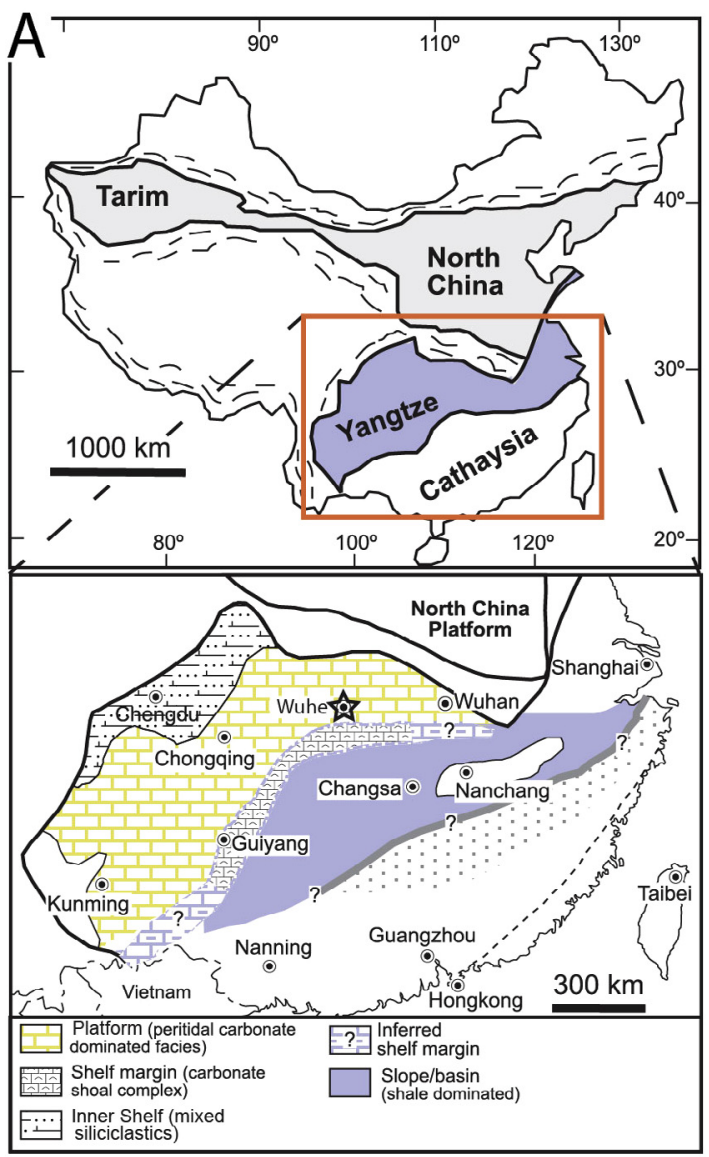

B

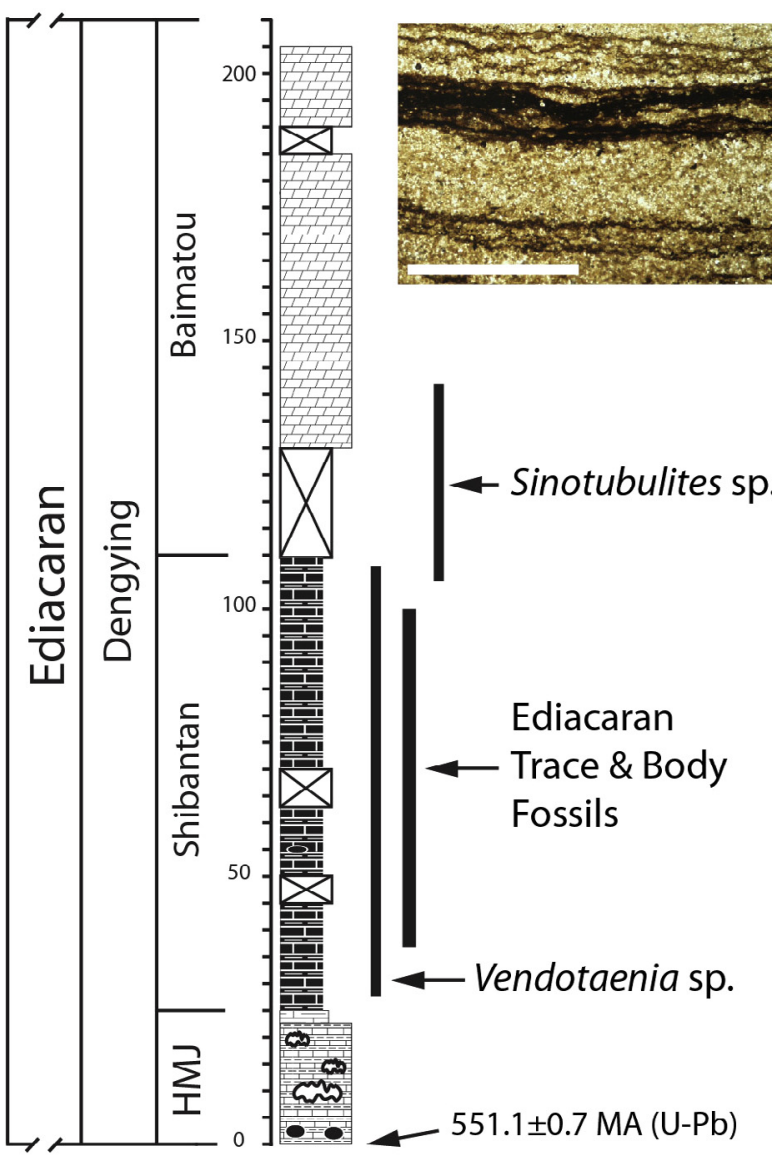

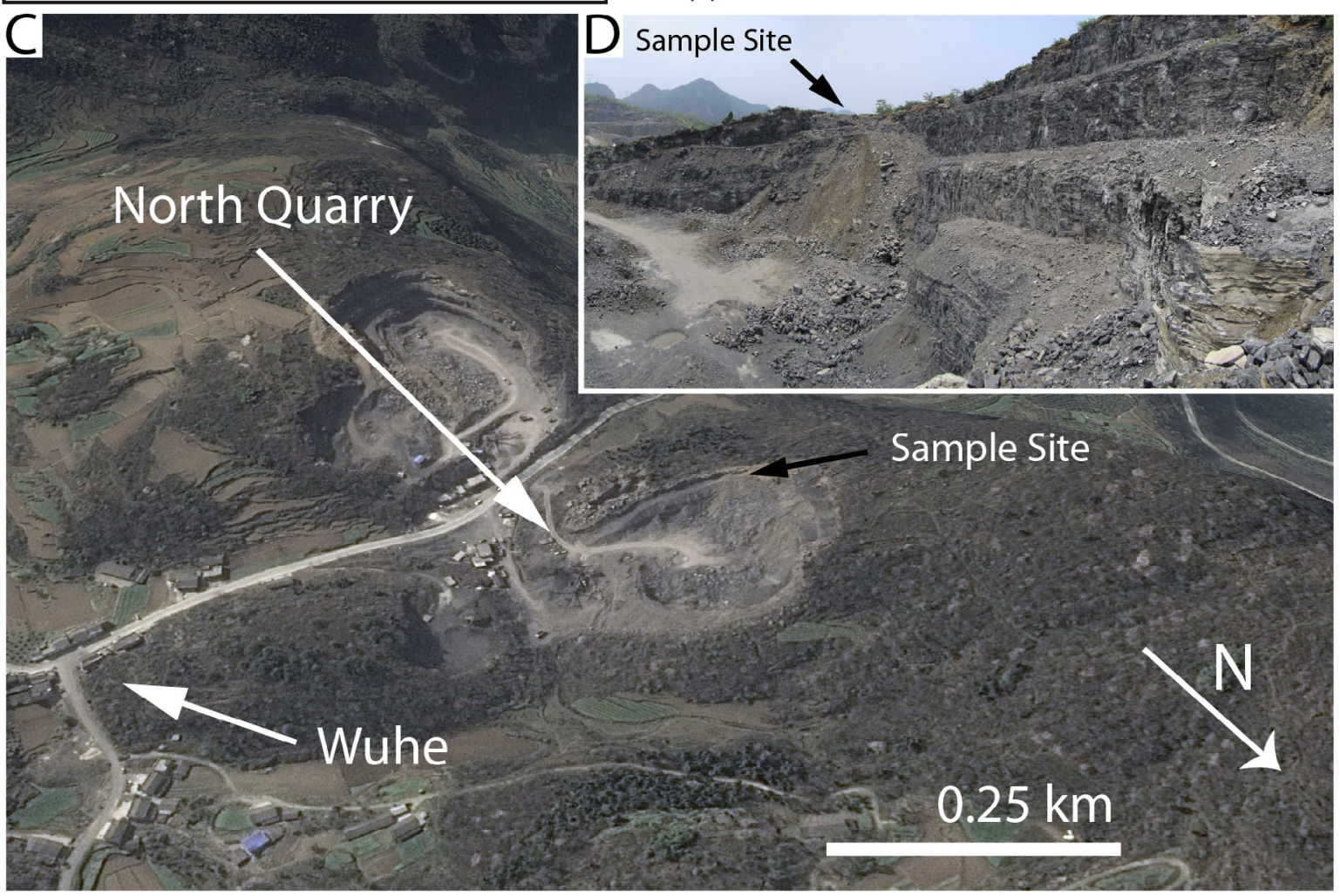

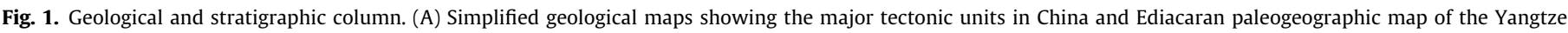

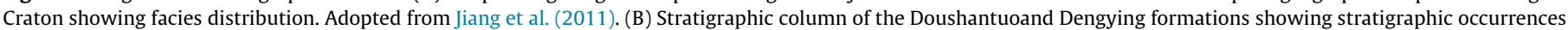

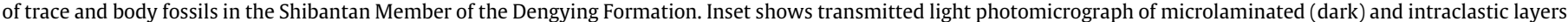

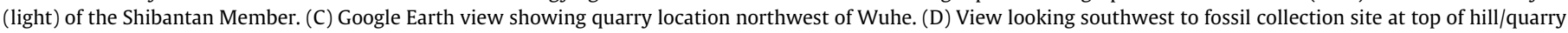
wall. Scale bar in inset of $B=1 \mathrm{~cm}$. 

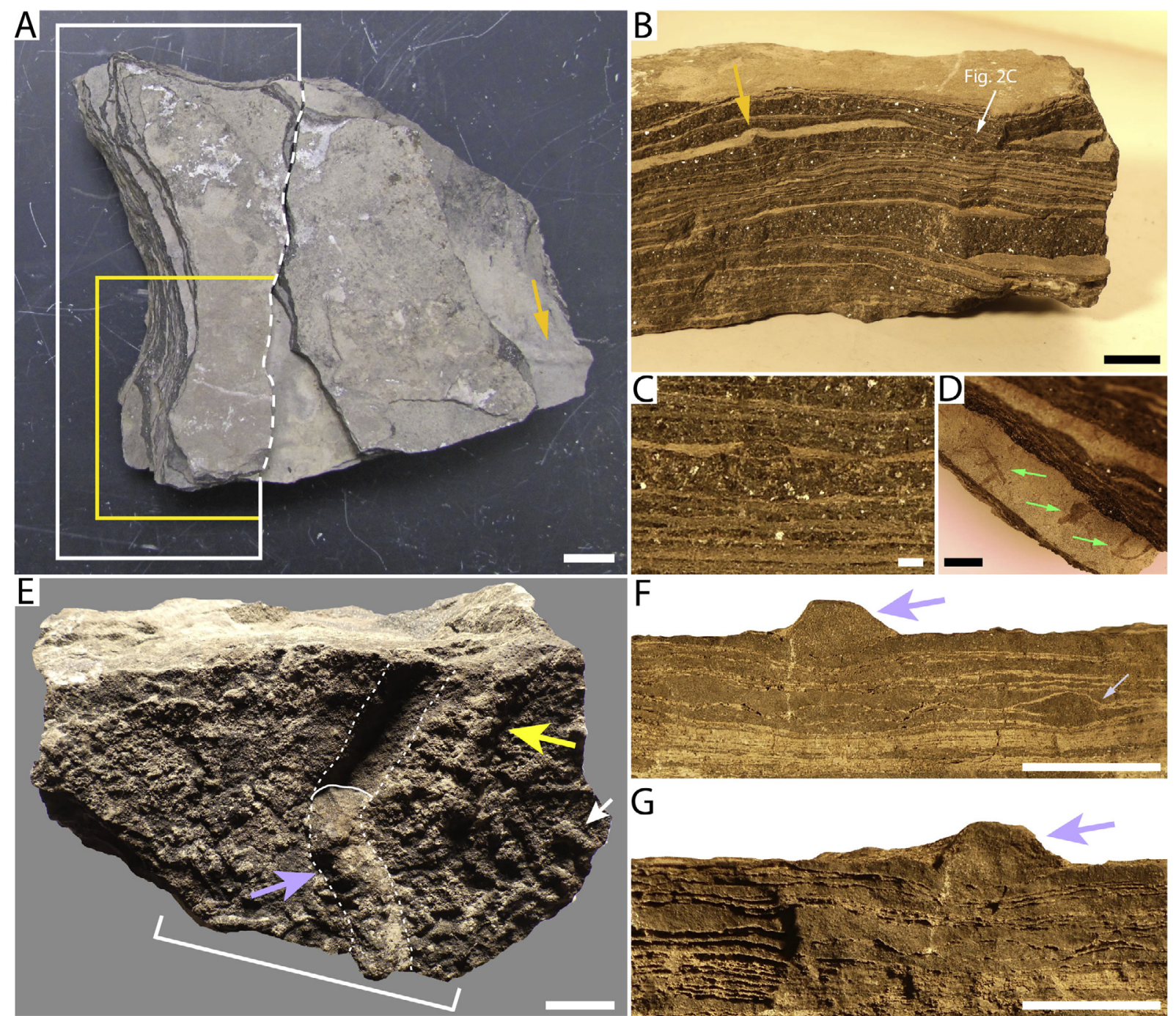

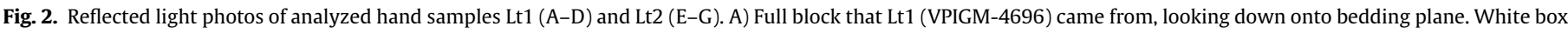

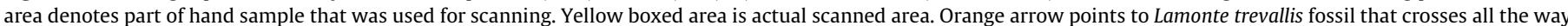

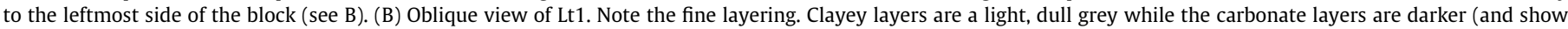

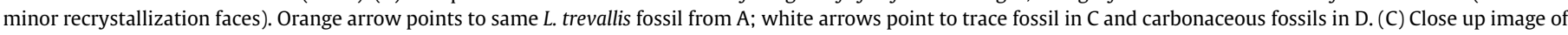

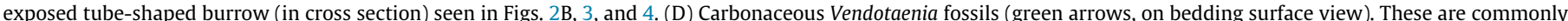

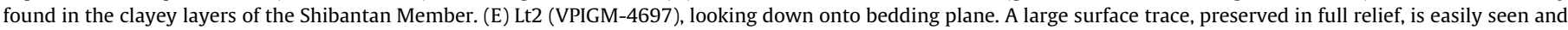

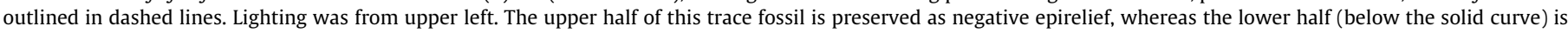

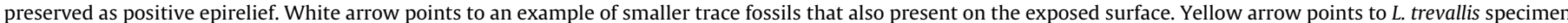

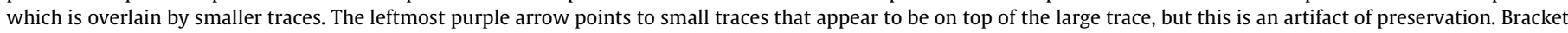

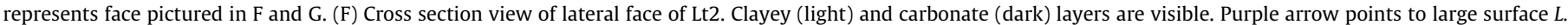

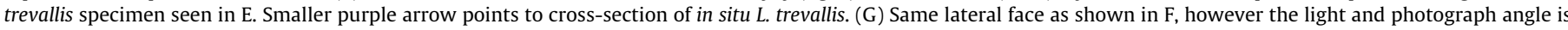

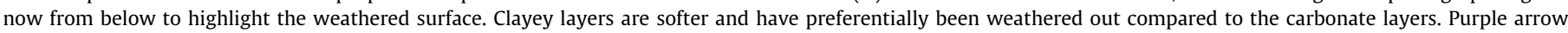

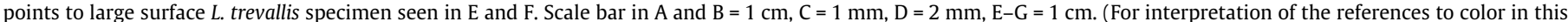
figure legend, the reader is referred to the web version of this article.)

ples per view over 180 degrees of rotation. The field of reconstruction was $90 \mathrm{~mm}$ for Lt1 resulting in $0.034 \mathrm{~mm}$ in-plane resolution.

The scan data were processed to reduce ring and beamhardening artifacts, and 16bit TIFF image stacks were reconstructed (1924 slices). The stack of images was further processed using open-source image processing, segmentation, and volume rendering tools to create $3 \mathrm{D}$ reconstructions of the features of interest. Because of the large size of the original data volumes ( $2.6 \mathrm{~Gb}$ for $\mathrm{Lt} 1$ ), the images were reduced to $1024 \times 1024$ pixels and 8bit depth using Image (Schneider et al., 2012) to facilitate rendering. The resulting stack was saved as a RAW file and then converted to NRRD format using the command line utility UNU (2013) for initial rendering and import into segmentation software.

\subsection{CT analysis of Lt2}

Lt2 (VPIGM-4697) was scanned via CT (Figs. 3 and 4) using a Siemens SOMATOM Emotion 6 at Smithsonian Museum of Natural History in Washington, DC, USA. An X-ray source operating at $130 \mathrm{kV}$ and $100 \mathrm{~mA}$ was employed, resulting in 389 slice images with an inter-slice spacing of $0.63 \mathrm{~mm}$. The CT scanner output the data in the DICOM format, which were exported as a series of JPG images using the software OsiriX (Rosset et al., 2004). The stacks of images were filtered in MATLAB to correct ring-shaped artifacts through use of a script for subtracting fixed pattern noise. The resulting corrected images were compiled into the NRRD format with UNU. The NRRD file was then imported into Seg3D and 

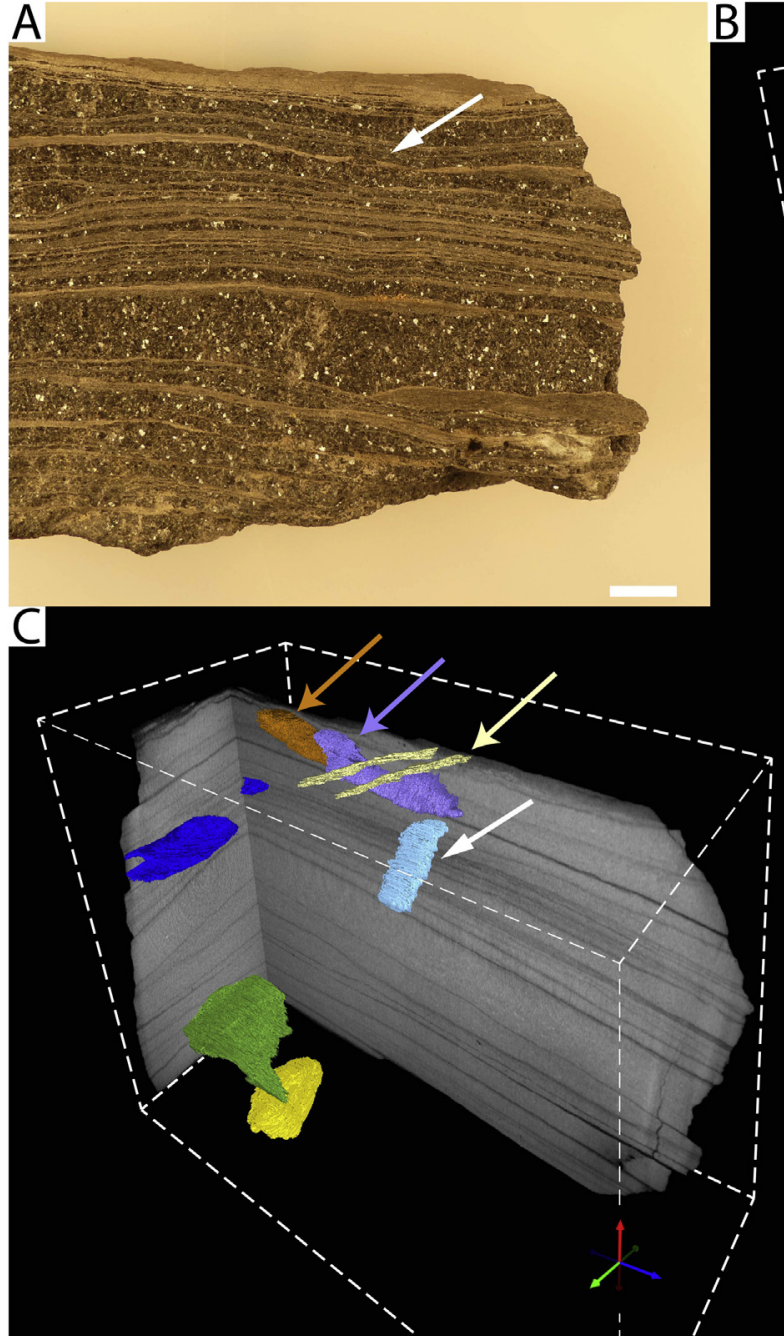
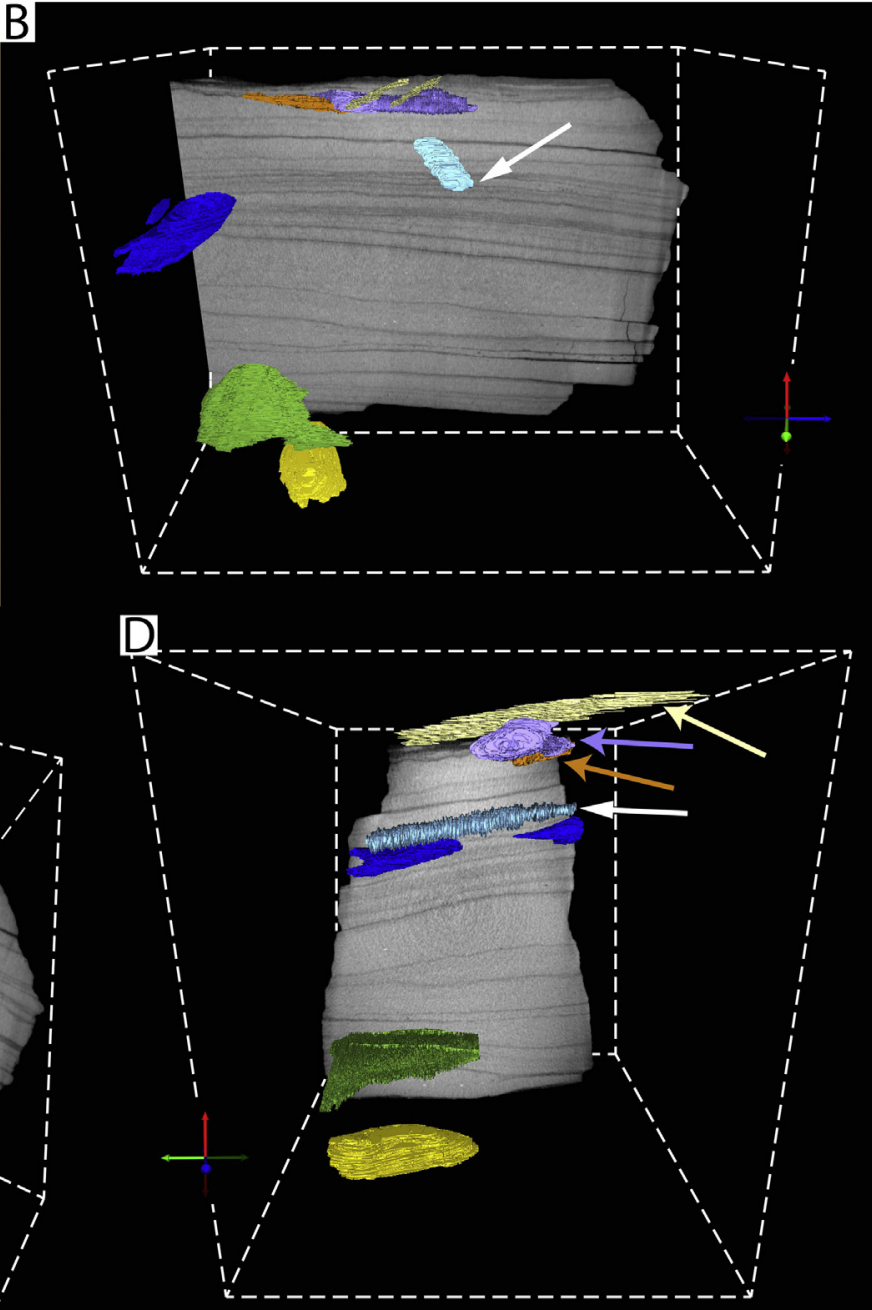

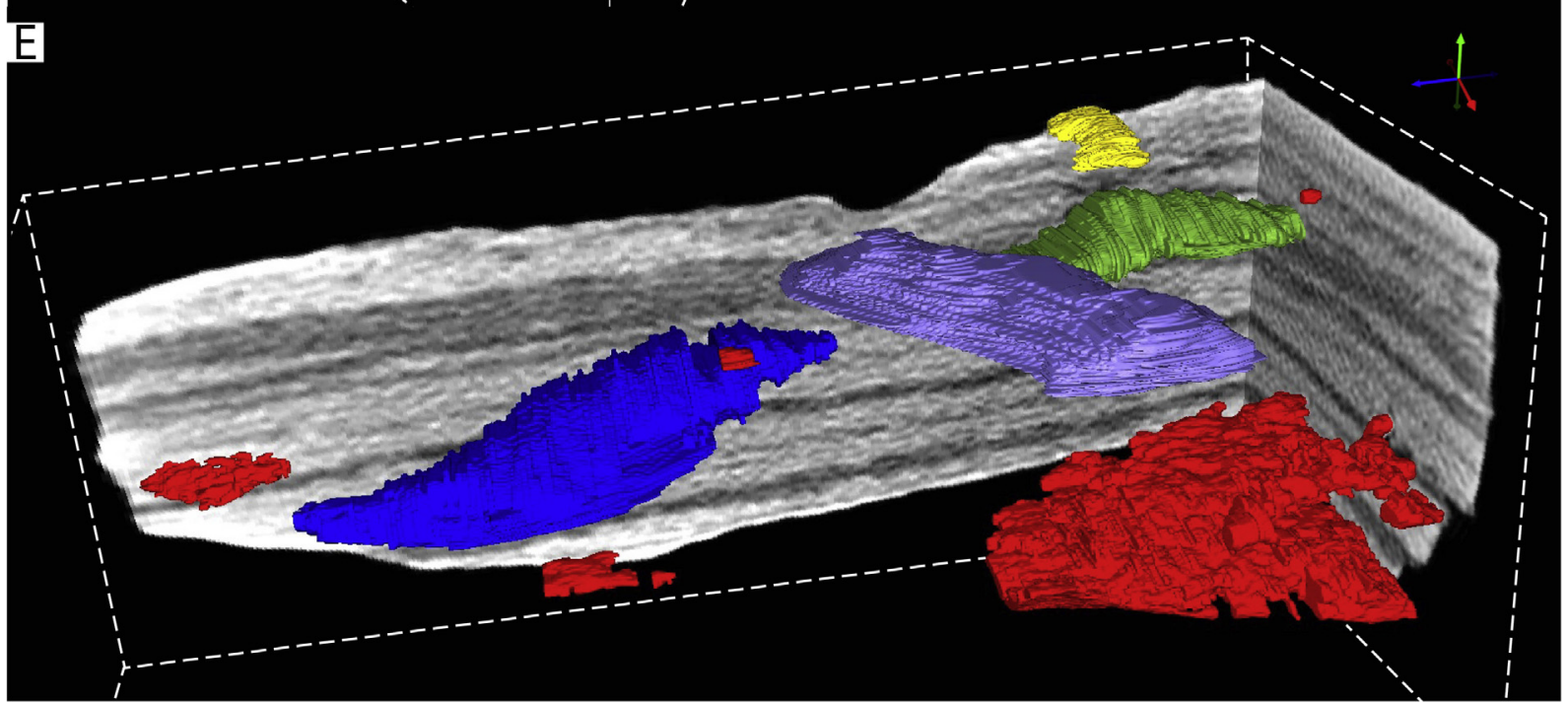

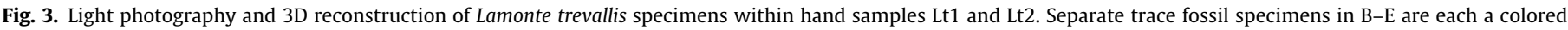

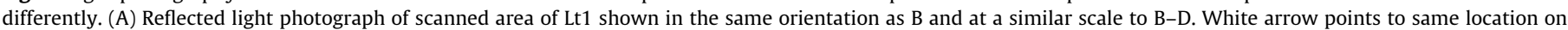

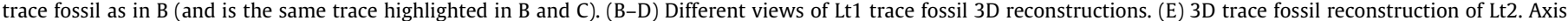
guide is located at the same point in space in B-D. Scale bar in A is $=50 \mathrm{~mm}$. 

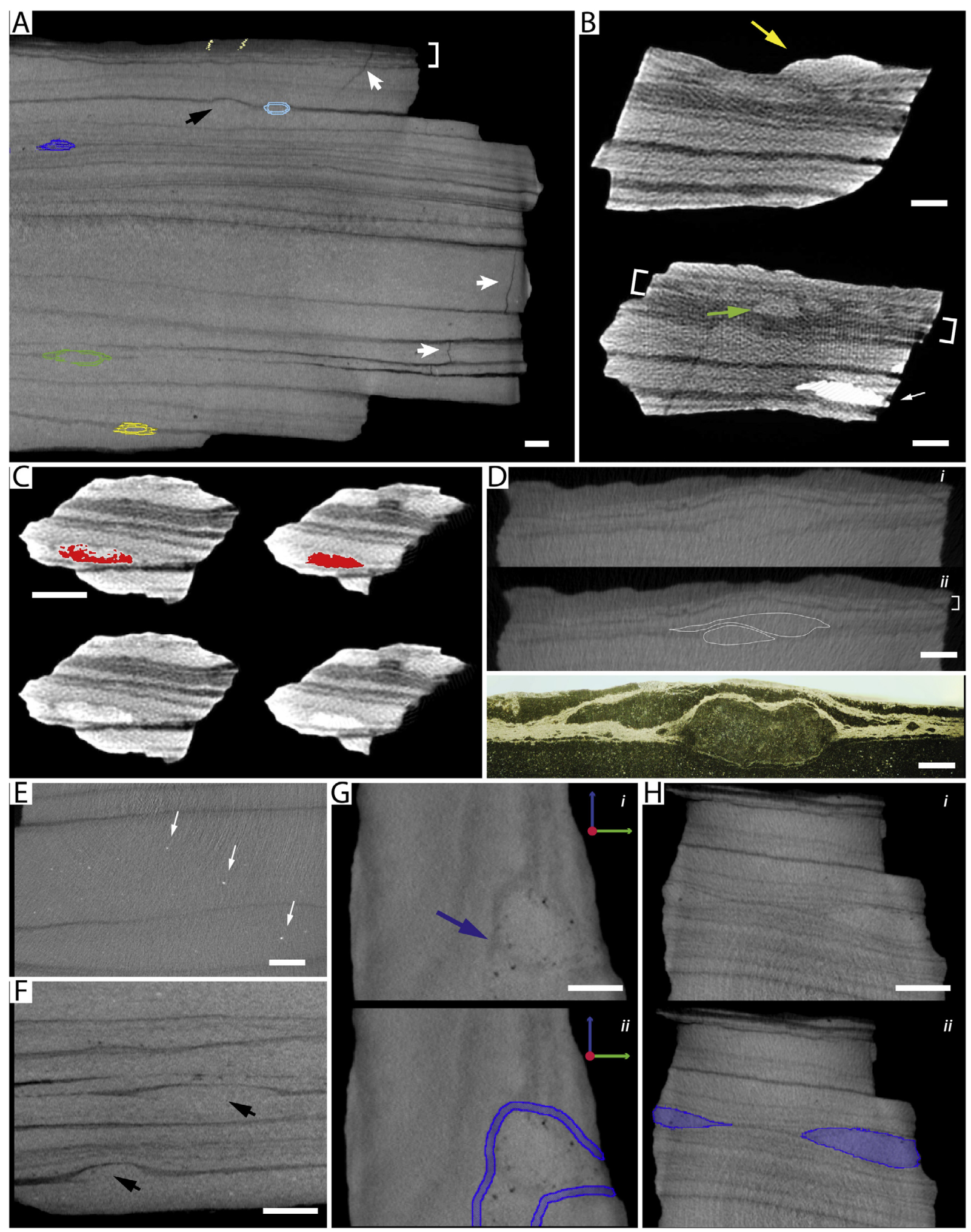

Fig. 4. CT and MicroCT imagery of hand samples Lt1 (A, D-H) and Lt2 (B and C). (A) Cross section along long axis of Lt1 showing trace fossil locations (colored). Black arrow points to flattened trace next to blue tube-shaped trace (same trace as seen in Figs. $2 \mathrm{C}$ and $3 \mathrm{~A}$ ). White arrows point to vertical cracks in the hand sample. Layer containing numerous burrows is within white bracket. (B) Scan imagery of Lt2 showing clayey (dark) and carbonate (light) layers. Yellow arrow points to large exposed trace. Layer containing many burrows are within white brackets, with green arrow pointing to an unexposed trace. White arrow points to highly pyritized trace in C. (C) Scan imagery of Lt2 with pyritized burrow highlighted (top two slices) and not highlighted (lower two slices). (D) MicroCT slices vs reflected light image of Lamonte trevallis traces on top of each other. $\left(D_{i}\right)$ Magnified view of scan image slice focusing on trace-bearing layer bracketed in $(A)$. ( $\left.D_{i i}\right)$ Same image as Ci, with L. trevallis cross-section interactions highlighted with white line. Lowermost picture is cross-section of L. trevallis specimens in reflected light (same specimen as fig. 5F of Meyer et al., 2014b). (E) Close-up of scan image slice of Lt1 (along the axis of the scanner, hence slight 'ring effect'). White dots are pyrite grains in carbonate layers; three especially bright ones are marked by white arrows. (F) Flattened traces. Black arrows point to apparent 'missing' lower bounds of trace (which is a resolution artifact). (G) Possible habitation node or vertical trace, viewed looking down onto the bed surface (but slightly askew from level; hence the appearance of layers). Blue arrow in Gi points to difference between interior trace composition and outside matrix. In Gii there is a blue outline around feature. Axis indicators in upper right corners match those of Lt1 in Fig. 2. (H) Lateral pinch-out of trace fossils is highlighted in Hii and not in $\mathrm{Hi}$. Scale Bars in $\mathrm{A}-\mathrm{C}=5 \mathrm{~mm}, \mathrm{D}-\mathrm{G}=1 \mathrm{~mm}, \mathrm{H}=2 \mathrm{~mm}$. (For interpretation of the references to color in this figure legend, the reader is referred to the web version of this article.) 
segmented into individual fossil traces using a combination of manual mask-painting and semi-automated tools.

\subsection{Data processing procedure}

The volumes for both Lt1 and Lt2 were then segmented into individual fossil traces by a combination of manual mask painting and semi-automated tools available in Seg3D (CIBC, 2013), an image processing and segmentation application built on ITK (Yoo et al., 2002). The segment masks of interest (individual specimens) were then exported as image stacks, resized using ImageJ to a useable $258 \times 258 \times 258$ voxels for real-time rendering, and converted to NRRD using UNU. Finally, the NRRD segments were composited and rendered using H3D (Sensegraphics, 2013), an X3D browser with strong support for NRRD and the volume rendering styles provided by the X3D 3.3 standard (Brutzman and Daly, 2007; Consortium, 2016). Each segment was represented as an isosurface and uniquely false-colored for easy visualization (Fig. 3). The original microCT data, along with all reslicings and derivative animations are deposited online at Morphobank.org, in a special project link (http://morphobank.org/permalink/?P2562).

\section{Analytical results}

Both CT and microCT scans (Figs. 3 and 4; see also Appendix A. Supplementary data) revealed similar lithological information in fine detail. The carbonate matrix is lighter (i.e., more X-ray attenuation) than the dark clayey layers, which is the opposite of the reflected light appearance (Fig. 2F). Lamina as thin as $0.5 \mathrm{~mm}$ in CT and $0.1 \mathrm{~mm}$ in microCT can be observed (Fig. 4A-D) with the truncation and separation of clayey layers by the traces clearly visible in 2D slices (Fig. 4).

Voids, joints, or cracks in the rocks appear black (Fig. 4A). The separation of layers along bedding planes is the most frequent type of void observed, primarily within the clayey layers (Fig. 4C). Cracks within the carbonate layers are usually vertical and connected to other cracks along surrounding clayey beds. Pyrite is present as bright white spots or areas in the scan images (Fig. 4C, E). Lt2 has numerous large pyritic chunks (Fig. 4B and C) that occur in both carbonate and clayey layers. Interestingly, Lt2 also has the only known pyritized $L$. trevallis trace known (red color, Fig. 4C); previous to this find it was not known that $L$. trevallis traces could be pyritized. Lt1 does not have any large concentrations of pyrites, but many small pyrite crystals occur in the carbonate layers (Fig. 4E).

The Lamonte trevallis fossils in these analyzed hand samples exhibit behavioral patterns similar to those inferred from petrographic thin section observations (Meyer et al., 2014b). Some layers contain only a single trace while others contain numerous burrows and tracks (Fig. 4A and B). Each hand sample analyzed contained a unit where there were so many traces that it was difficult to parse out individual burrows successfully (see bracketed layers in figures); these units were left out of the reconstructions since the entire units would have to be used rather than individual traces. Lamonte trevallis specimens recognized in scan imagery vary in size in both Lt1 and Lt2 due to differences in actual trace size, compression or flattening, taphonomic overgrowth due to recrystallization, and scanning resolution (Fig. 3). Their morphologies range from narrow to wider tube-shaped burrows that are ellipsoidal in cross-section. Most burrows scanned are rather small, only a few millimeters in width and a couple of centimeters in length (Fig. 3C, E). However, the largest surface specimen on Lt2 is almost $1 \mathrm{~cm}$ in width and up to $6 \mathrm{~cm}$ in length (purple specimen in Fig. 3E).

Tube-shaped burrows can be followed along most of their course (white arrow, Fig. 3A-D); although in layers where burrows are dense it can be difficult to follow a single trace to its termination (Fig. 4B). Burrows do not appear to intersect each other (Fig. 3), but they can be found over-lapping each other (colored arrows, Fig. $3 \mathrm{C}$ and D). Flattening of traces along their path is a common phenomenon. Flattened traces (Fig. 4F), while much fainter than the more three-dimensionally preserved burrows, can still retain some of their collapsed morphology (e.g., archshaped transverse profile). These interior features are difficult to resolve because they are so close in size to the resolution limit of the microCT scans and they cannot be resolved in CT scan data. Vendotaenia specimens are found on numerous layers of both scanned specimens, especially on some layers on Lt1 (Fig. 2D). However, they do not appear on the microCT imagery though they are within the resolution of the detector. This could be due to low contrasting densities between the fossils and the matrix, especially if they are clay imprints rather than fully carbonaceous fossils (Anderson et al., 2011; Meyer et al., 2012, 2016).

\section{Taphonomic and paleoecological discussion}

The scans of Lamonte trevallis reveal interesting features not observed in previous studies. The morphology of the tube-shaped burrows is surprisingly robust over numerous scales. Small and large burrows have roughly the same aspect ratios in cross section (i.e., minimum width vs. maximum width ratios of about 1:4). This may suggest a trace maker that keeps a consistent body shape through its lifecycle or a common degree of compaction. We argue for the former, as other burrow fossils (such as Helminthoidichnites) in the same formation, which would have undergone the same compaction pressures, are often preserved as highly collapsed or flattened features (Steiner et al., 2001; Weber et al., 2007). There continues to be no evidence for backfilling in the internal structure of the fossils. This may be a function of resolution (present, but not detected) or it may be not present at all. There appears to be some evidence for possible domichnia (habitation) areas (the vertical component as described in Meyer et al., 2014b) in a circular trace that has two tubes coming out of it at right angles (Fig. 4G). This study did not find evidence for feeding patterns (either grazing or hunting fodinichnia) or true multi-nodal networks, but this is likely a sampling effect of such small hand samples scanned in this study. The pyritization of some traces (Fig. 4C) indicate that there could be significant amounts of organic matter in the traces. Whether this organic matter was derived from food or fecal matter is not apparent from the scan data. Larger slabs would likely result in more trace network data; however, there are still technical difficulties in scanning larger slabs. If those technical methods can be overcome, information gained could be used to further investigate key events in the evolution of animals that significantly impact the geobiological dynamics at the Ediacaran-Cambrian transition.

\section{Estimating bioturbation intensity: 3D vs. 2D}

A major disadvantage of traditional ichnological and petrographic methods is the reliance on generally two-dimensional data: exposure surfaces and (petrographic) thin sections (Bednarz and Mcllroy, 2009). Extracting trace fossil data from surface exposures has a long history (Seilacher, 2007), but there is still much difficulty studying them if the traces are small, difficult to discern, or have a complex relationship with the host matrix. Thin sections can reveal a remarkable amount of information, but they do not cover large areas and require laborious preparation. The use of Xray commuted tomography (CT) can image a rock sample in minutes and, with the right software in hand, lead to almost instantaneous data analysis (Gingras and Smith, 2015). This is one of the reasons why the oil and gas industry has moved to the use of CT 
and microCT analysis of cored geological materials (for rapid acquisition of important porosity, permeability, density, and structural information), although it is taking some time for these results to get into the non-proprietary sphere (Gingras and Smith, 2015). Serial grinding and Magnetic Resonance Imaging (MRI) have been used more frequently in paleontology and ichnology, although both are more time consuming than CT methods (Gingras and Smith, 2015; Gingras et al., 2002; Leaman and McIlroy, 2016).

The more widespread use of 3D datasets to investigate traces has implications for numerous aspects of paleoichnology. Surface bias in modeling trace morphology can be mitigated using 3D analysis since an investigator can swipe through slices of data and examine a specimen from all angles, creating their own 'virtual surfaces' and cross-sections. Sub-surface bias can also be lessened since the within-matrix (or in situ) morphology of the trace can better be fully imaged. The most significant implication of 3D data on ichnology is on studies related to bioturbation intensity and bioturbation index. This is especially important near the Ediacaran-Cambrian boundary where metazoan 'ecosystem engineering' has been invoked as a driver for the disappearance of the unique Ediacara fossils (Darroch et al., 2015; Erwin and Tweedt, 2012; Laflamme et al., 2013). A method that provides quantitative measures for bioturbation and sediment mixing during this critical interval could have important applications. Bioturbation intensity (BI) has generally two components (horizontal and vertical), which show different aspects of infaunal behavior; the vertical component is usually the one used to analyze advances or innovation in trace making (Droser et al., 2005b, 2006; Seilacher, 2007; Tarhan et al., 2015). Here we propose an adjusted BI for 3D data, the Volumetric Bioturbation Intensity (VBI).

\subsection{Volumetric bioturbation intensity (VBI)}

The VBI is similar to the traditional BI in that it is a measurement of bioturbation on a percentage basis, but it is based on three-dimensional volumetric measurements rather than twodimensional areal measurements. All computational work follows from the calculation of voxel size. Pixels are the smallest addressable element in a 2D image ( same element, but with 3D data (size=volume). Since 3D data are collected as 2D slices which are stacked into a 'volume set' (and thereafter considered volume data), any volume analysis will have gaps in the data. These gaps can be micron-sized for interslice gaps in CT imaging or up to millimeter-sized gaps between surface images in serial grinding (depending on the features examined). The gap distance needs to be incorporated into voxel size. Hence, imaging pixel size multiplied by the gap distance gives the voxel size. Many scanning devices and 3D imaging software can automatically generate voxel size, but these numbers should always be confirmed (CIBC, 2013).
Once voxel size is calculated, then the actual volume of both the rock sample and traces can be calculated, and the following equation can be used:

$R_{t}=S_{t}-E_{t}$

where $S_{t}$ is the total scanned volume, $E_{t}$ is the total 'empty' scanned volume that surrounds the rock sample, and $R_{t}$ is the total rock sample volume. This equation may not always need to be used, but takes into account for the excess space surrounding a specimen that may otherwise be difficult to differentiate in 3D reconstruction software. Once $R_{t}$ is known, then VBI can be calculated in a similar manner to the traditional $\mathrm{BI}$ :

$\frac{T_{t}}{R_{t}} * 100$

where $R_{t}$ is still the total rock sample volume, and $T_{t}$ is the total trace volume.

\subsection{Lamonte trevallis VBI}

Using the above measurements and equations, the VBI of the scanned $L$. trevallis specimens can be calculated (Table 1 ). The VBI of Lt 1 and Lt2 are $1.32 \%$ and $1.81 \%$, respectively. The consistency of the VBI between the two samples shows a robustness for the calculation of this ichnogenus, even when the scale of the fossils and analytical technique differs. The VBI is much lower than the vertical and horizontal BI that has been previously reported for this fossil (Meyer et al., 2014b), which ranged from a horizontal BI or $\sim 40 \%$ to a vertical BI of $\sim 5 \%$. This could be due to a sampling bias for two reasons: 1 ) the previous calculation of horizontal BI omitted bedding surfaces without traces, and 2) this study underestimates the amount of bioturbation because layers with densely packed trace fossils were not included in the analysis due to segmentation difficulties. In both Lt1 and Lt2, there are layers that were completely bioturbated that were left out of the VBI calculations; these units would have likely increased VBI by a few percent (bringing it more in line with previous estimates).

\section{Conclusions}

One of the most important innovations in the early evolution of animal bioturbation was the exploration and penetration of the ubiquitous microbial mats that were present throughout the Precambrian. The development of bioturbation led to deeper sediment infiltration and greater geobiological dynamics at the EdiacaranCambrian transition; Lamonte trevallis epitomizes early development of bioturbation. The unique preservation of the $L$. trevallis burrows has enabled effective 3-D imaging via CT and microCT scans, although each analytical method has its own advantages and disadvantages. CT scans resolve sedimentological and

Table 1

Volume of traces in hand samples Lt1 and Lt2. VBI is also shown.

\begin{tabular}{|c|c|c|c|c|c|}
\hline Sample Name & Specimen Color & Volume $\left(\mathrm{cm}^{3}\right)$ & Sample Name & Specimen Color & Volume $\left(\mathrm{cm}^{3}\right)$ \\
\hline Lt1 & Purple & 0.11 & Lt2 & Purple & 0.72 \\
\hline Lt1 & Orange & 0.08 & Lt2 & Blue & 0.65 \\
\hline Lt1 & Green & 0.24 & Lt2 & Green & 0.44 \\
\hline Lt1 & Dark Blue & 0.19 & Lt2 & Yellow & 0.09 \\
\hline Lt1 & Yellow & 0.10 & Lt2 & Red (Pyrite) & 1.24 \\
\hline Lt1 & Light Blue & 0.05 & Total Lt2 & & 1.90 \\
\hline Total Lt1 & & 0.77 & Total Rock Vol. & & 105 \\
\hline Total Rock Vol. & & 58 & VBI (\%) & & 1.81 \\
\hline VBI (\%) & & 1.32 & & & \\
\hline
\end{tabular}


paleontological information of relatively large specimens at millimeter-scale resolution. MicroCT scans can have ultra-high resolution $(\sim 0.1 \mathrm{~mm})$, but can only be used with small samples and may involve more post-processing than CT scans. When used in combination, these methods allow the calculation of VBI that provides a more accurate and quantitative assessment of bioturbation in three dimensions.

A more widespread application of this methodology could stimulate resurgence in trace fossil research. This type of data is also easily adaptable for educational purposes and general outreach activities. Increasingly there are more publicly available data repositories (for the large amounts of data created by CT analysis) and more outreach initiatives looking for 3D or augmented-reality datasets for discovery-based teaching. The development of inexpensive 3D viewing platforms (such as the Oculus Rift, HTC Vive, or Microsoft Hololens) means that accessing these data, in 3D, is simpler (and cheaper) than ever before. The preliminary success of CT scanning of fairly simple traces demonstrated here opens up the opportunity for analysis of many other traces (of any geologic era) in new and imaginative ways while also expanding our understanding of Earth's first bioturbators.

\section{Acknowledgements}

This work was supported by the Paleontological Society (AJ Boucot Award), Bucknell University, Virginia Tech, and the Nanjing Institute of Geology and Palaeontology (NIGP). We would like to especially thank Pang Ke, Zhe Chen, Chuanming Zhou, and Xunlai Yuan from the NIGP and Jennifer Sliko (Penn State Harrisburg) for their help, without which we could not have done this work. We also thank Dave Hunt of the Smithsonian Institution, Washington, DC and Brandon Walters of Micro Photonics of Allentown, PA for scanning the analyzed specimens and Russell Hardie of University of Dayton for developing original scripts to remove signal artifacts. Yaqoob gratefully acknowledges his internship in Johns Hopkins University's Open Earth Systems Project that is funded by the NSF Frontiers in Earth System Dynamics Program (award EAR-1135382). Xiao acknowledges funding from the NSF Sedimentary Geology and Paleobiology Program (EAR-1528553) and NASA Exobiology and Evolutionary Biology Program (NNX15AL27G).

\section{Appendix A. Supplementary data}

Supplementary data associated with this article can be found, in the online version, at http://dx.doi.org/10.1016/j.precamres.2017. 05.010.

\section{References}

Abel, R.L., Laurini, C.R., Richter, M., 2012. A palaeobiologist's guide to 'virtual' microCT preparation. Palaeontol. Electron. 15, 17.

Anderson, E., Schiffbauer, J.D., Xiao, S., 2011. Taphonomic study of organic-walled microfossils confirms the importance of clay minerals and pyrite in Burgess Shale-type preservation. Geology 39, 643-646.

Bednarz, M., Mcllroy, D., 2009. Three-dimensional reconstruction of "Phycosiphoniform" burrows: implications for identification of trace fossils in core. Palaeontol. Electron. 12, 15.

Bertling, M., 2007. What's in a Name? Nomenclature, Systematics, Ichnotaxonomy. In: Miller, W. (Ed.), Trace Fossils: Concepts, Problems, Prospects. Elsevier, Amsterdam, The Netherlands, pp. 81-91.

Brutzman, D., Daly, L., 2007. X3D: Extensible 3D Graphics for Web Authors. Morgan Kaufmann Publishers Inc., San Francisco, CA.

Budd, G.E., Jackson, I.S.C., 2016. Ecological innovations in the Cambrian and the origins of the crown group phyla. Philos. Trans. R. Soc. London B 371. http://dx. doi.org/10.1098/rstb.2015.0287.

Chen, Z., Zhou, C., Meyer, M., Xiang, K., Schiffbauer, J.D., Yuan, X., Xiao, S., 2013a. Trace fossil evidence for Ediacaran bilaterian animals with complex behaviors. Precambrian Res. 224, 690-701.

Chen, Z., Zhou, C., Meyer, M., Xiang, K., Schiffbauer, J.D., Yuan, X., Xiao, S., 2013b. Reply to comment on "Trace fossil evidence for Ediacaran bilaterian animals with complex behaviors" [Precambrian Res. 224 (2013) 690-701]. Precambrian Res. 231, 386-387.

Chen, Z., Zhou, C., Xiao, S., Wang, W., Guan, C., Hua, H., Yuan, X., 2014. New Ediacara fossils preserved in marine limestone and their ecological implications. Sci. Rep. 4,4180 .

CIBC, 2013. Seg3D: Volumetric image segmentation and visualization, in: Institute, U.o.U.S.C.a.I. (Ed.), Seg3D. University of Utah Scientific Computing and Imaging Institute.

Condon, D., Zhu, M., Bowring, S., Wang, W., Yang, A., Jin, Y., 2005. U-Pb ages from the Neoproterozoic Doushantuo Formation, China. Science 308, 95-98.

Consortium, W.D., 2016. Extensible 3D (X3D) specifications: ISO/IEC 19775-1 (Abstract Spec), ISO/IEC 19775-2 (SAI), ISO/IEC 19776-1 (XML Encoding), ISO/ IEC 19776-2 (utf-8 Encoding, ISO/IEC), 19776-3 (Binary Encoding), in: Consortium, W.D. (Ed.), X3D Spec. Web3D Consortium.

Darroch, S.A.F., Sperling, E.A., Boag, T.H., Racicot, R.A., Mason, S.J., Morgan, A.S. Tweedt, S., Myrow, P., Johnston, D.T., Erwin, D.H., Laflamme, M., 2015. Biotic replacement and mass extinction of the Ediacara biota. Proc. R. Soc. London B 282. http://dx.doi.org/10.1098/rspb.2015.1003.

Dong, L., Xiao, S., Shen, B., Zhou, C., Li, G., Yao, J., 2009. Basal Cambrian microfossils from the Yangtze Gorges area (South China) and the Aksu area (Tarim Block, northwestern China). J. Paleontol. 83, 30-44.

Droser, M.L., Gehling, J.G., Jensen, S., 1999. When the worm turned: concordance of early cambrian ichnofabric and trace-fossil record in siliciclastic rocks of South Australia. Geology 27, 625-628.

Droser, M.L., Gehling, J.G., Jensen, S., 2005. Ediacaran trace fossils: “Tubey” or not to be. GSA Annual Meeting Abstracts with Programs 37(7) 484

Droser, M.L., Gehling, J.G., Jensen, S., 2005b. Ediacaran trace fossils: true and false. In: Briggs, D.E.G. (Ed.), Evolving Form and Function: Fossils and Development. Yale Peabody Museum Publications, New Haven, CT, pp. 125-138.

Droser, M.L., Gehling, J.G., Jensen, S.R., 2006. Assemblage palaeoecology of the Ediacara biota: The unabridged edition? Palaeogeogr. Palaeoclimatol. Palaeoecol. 232, 131-147.

Droser, M.L., Jensen, S., Gehling, J.G., 2002. Trace fossils and substrates of the terminal Proterozoic-Cambrian transition: Implications for the record of early bilaterians and sediment mixing. Proc. Natl. Acad. Sci. U.S.A. 99, 1257212576.

Duda, J.-P., Blumenberg, M., Thiel, V., Simon, K., Zhu, M., Reitner, J., 2014. Geobiology of a palaeoecosystem with Ediacara-type fossils: The Shibantan Member (Dengying Formation, South China). Precambrian Res. 255 (Part 1), 48-62.

Erwin, D.H., Tweedt, S., 2012. Ecological drivers of the Ediacaran-Cambrian diversification of Metazoa. Evol. Ecol. 26, 417-433.

Gingras, M., Hagadorn, J.W., Seilacher, A., Lalonde, S.V., Pecoits, E., Petrash, D., Konhauser, K.O., 2011. Possible evolution of mobile animals in association with microbial mats. Nat. Geosci. 4, 372-375.

Gingras, M., Smith, M., 2015. Bioturbation: reworking sediments for better or worse. Oilfield Rev. 26, 46-588.

Gingras, M.K., MacMillan, B., Balcom, B.J., Saunders, T., Pemberton, S.G., 2002. Using magnetic resonance imaging and petrographic techniques to understand the textural attributes and porosity distribution in macaronichnus-burrowed sandstone. J. Sediment. Res. 72, 552-558.

Hagadorn, J.W., Xiao, S., Donoghue, P.C.J., Bengtson, S., Gostling, N.J., Pawlowska, M. Raff, E.C., Raff, R.A., Turner, F.R., Yin, C., Zhou, C., Yuan, X., McFeely, M.B., Stampanoni, M., Nealson, K.H., 2006. Cellular and subcellular structure of Neoproterozoic embryos. Science 314, 291-294.

Jensen, S., Droser, M.L., Gehling, J.G., 2005. Trace fossil preservation and the early evolution of animals. Palaeogeogr. Palaeoclimatol. Palaeoecol. 220, 19-29.

Jensen, S., Droser, M.L., Gehling, J.G., 2006. A critical look at the Ediacaran trace fossil record. In: Xiao, S., Kaufman, A.J. (Eds.), Neoproterozoic Geobiology. Springer, Dordrecht, the Netherlands, pp. 115-157.

Jiang, G., Shi, X., Zhang, S., Wang, Y., Xiao, S., 2011. Stratigraphy and paleogeography of the Ediacaran Doushantuo Formation (ca. 635-551 Ma) in South China. Gondwana Res. 19, 831-849.

Jiang, G., Wang, X., Shi, X., Xiao, S., 2012. The origin of decoupled carbonate and organic carbon isotope signatures in the early Cambrian (ca. 542-520 Ma) Yangtze platform. Earth Planet. Sci. Lett., 317-318

Jiang, S.-Y., Pi, D.-H., Heubeck, C., Frimmel, H., Liu, Y.-P., Deng, H.-L., Ling, H.-F., Yang, J.-H., 2009. Early Cambrian ocean anoxia in South China. Nature 459, E5-E6.

Laflamme, M., Darroch, S.A.F., Tweedt, S.M., Peterson, K.J., Erwin, D.H., 2013. The end of the Ediacara biota: Extinction, biotic replacement, or Cheshire Cat? Gondwana Res. 23, 558-573.

Leaman, M., McIlroy, D., 2016. Three-dimensional morphological and permeability modelling of diplocraterion. Ichnos 24, 51-63.

Maisano, J.A., Kearney, M., Rowe, T., 2006. Cranial anatomy of the spade-headed amphisbaenian Diplometopon zarudnyi (Squamata, amphisbaenia) based on high-resolution X-ray computed tomography. J. Morphol. 267, 70-102.

Malpas, J.A., Gawthorpe, R.L., Pollard, J.E., Sharp, I.R., 2005. Ichnofabric analysis of the shallow marine Nukhul Formation (Miocene), Suez Rift, Egypt: implications for depositional processes and sequence stratigraphic evolution. Palaeogeogr. Palaeoclimatol. Palaeoecol. 215, 239-264.

Meyer, M., Elliott, D., Wood, A.D., Polys, N.F., Colbert, M., Maisano, J.A., Vickers-Rich, P., Hall, M., Hoffman, K.H., Schneider, G., Xiao, S., 2014a. Three-dimensional microCT analysis of the Ediacara fossil Pteridinium simplex sheds new light on its ecology and phylogenetic affinity. Precambrian Res. 249, 79-87.

Meyer, M., Polys, N., 2015. Trace fossils in 3d! Micro-CT reconstructions of the Late Ediacaran trace fossil Lamonte trevallis, from the Yangtze Gorges area, South China. Geol. Soc. Am. Abstr. Programs 47, 852. 
Meyer, M., Schiffbauer, J.D., Xiao, S., Cai, Y., Hua, H., 2012. Taphonomy of the upper Ediacaran enigmatic ribbonlike fossil Shaanxilithes. Palaios 27, 354-372.

Meyer, M.B., Broce, J., Selly, T., Schiffbauer, J.D., 2016. Insights into Vendotaenid taphonomy and structure New data on an old fossil. Geol. Soc. Am. Abstr. Programs 48.

Meyer, M.B., Xiao, S., Gill, B.C., Schiffbauer, J.D., Chen, Z., Zhou, C., Yuan, X., 2014b. Interactions between Ediacaran animals and microbial mats: Insights from Lamonte trevallis, a new trace fossil from the Dengying Formation of South China. Palaeogeogr. Palaeoclimatol. Palaeoecol. 396, 62-74.

Miller, W., 2007. Trace Fossils: Concepts, Problems, Prospects. Elsevier, Amsterdam.

Parry, L., Condon, D., Liu, A.G., Garwood, R., Mcllroy, D., 2015. An exceptionally preserved ichnofauna from the Ediacaran-Cambrian transition of the Corumba Group of Mato Grosso do Sul, Brazil. Geol. Soc. Am. Abstr. Programs 47, 572.

Rosset, A., Spadola, L., Ratib, O., 2004. OsiriX: an open-source software for navigating in multidimensional DICOM images. J. Digit. Imaging 17, 205-216.

Sappenfield, A., Droser, M.L., Gehling, J.G., 2011. Problematica, trace fossils, and tubes within the ediacara member (South Australia): redefining the ediacaran trace fossil record one tube at a time. J. Paleontol. 85, 256-265.

Schiffbauer, J.D., Xiao, S., Sen Sharma, K., Wang, G., 2012. The origin of intracellular structures in Ediacaran metazoan embryos. Geology 40, 223-226.

Schneider, C.A., Rasband, W.S., Eliceiri, K.W., 2012. NIH Image to ImageJ: 25 years of image analysis. Nat. Methods 9, 671-675.

Seilacher, A., 2007. Trace Fossil Analysis. Springer-Verlag, Heidelberg.

Sensegraphics, 2013. Open source haptics - H3D.org, in: Sensegraphics (Ed.), H3D.

Shen, B., Xiao, S., Zhou, C., Yuan, X., 2009. Yangtziramulus zhangi new genus and species, a carbonate-hosted macrofossil from the Ediacaran Dengying Formation in the Yangtze Gorges area, South China. J. Paleontol. 83, 575-587.

Shen, B., Xiao, S., Zhou, C., Dong, L., Chang, J., Chen, Z., 2017. A new modular palaeopascichnid fossil Curviacus ediacaranus new genus and species from the Ediacaran Dengying Formation in the Yangtze Gorges area of South China. Geol. Mag. http://dx.doi.org/10.1017/S001675681700036X.

Steiner, M., Zhu, M., Weber, B., Geyer, G., 2001. The Lower Cambrian of eastern Yunnan: Trilobite-based biostratigraphy and related faunas. Acta Palaeontologica Sinica 40 (supplement), 63-79.

Sun, W., 1986. Late Precambrian pennatulids (sea pens) from the eastern Yangtze Gorge, China: Paracharnia gen. nov. Precambrian Res. 31, 361-375.

Sutton, M.D., Briggs, D.E.G., Siveter, D.J., 2001. Methodologies for the visualization and reconstruction of three-dimensional fossils from the Silurian Herefordshire lagerstätte. Palaeontol. Electron. 4, 17.
Tarhan, L.G., Droser, M.L., Planavsky, N.J., Johnston, D.T., 2015. Protracted development of bioturbation through the early Palaeozoic Era. Nat. Geosci. 8, 865-869.

Tarhan, L.G., Planavsky, N.J., Laumer, C.E., Stolz, J.F., Reid, R.P., 2013. Microbial mat controls on infaunal abundance and diversity in modern marine microbialites. Geobiology 11, 485-497.

UNU, 2013. Teem: Tools to process and visualize scientific data and images, UNU.

Wan, B., Xiao, S., Yuan, X., Chen, Z., Pang, K., Tang, Q., Guan, C., Maisano, J.A., 2014 Orbisiana linearis from the early Ediacaran Lantian Formation of South China and its taphonomic and ecological implications. Precambrian Res. 255 (Part 1), 266-275.

Weber, B., Steiner, M., Zhu, M.Y., 2007. Precambrian Cambrian trace fossils from the Yangtze Platform (South China) and the early evolution of bilaterian lifestyles. Palaeogeogr. Palaeoclimatol. Palaeoecol. 254, 328-349.

Xiao, S., Shen, B., Zhou, C., Xie, G., Yuan, X., 2005. A uniquely preserved Ediacaran fossil with direct evidence for a quilted bodyplan. Proc. Natl. Acad. Sci. U.S.A. 102, 10227-10232.

Yaqoob, H., Hinnov, L., Meyer, M.B., 2015. CT reconstruction of Ediacaran trace fossils. Geol. Soc. Am. Abstr. Programs 47, 525.

Yoo, T.S., Ackerman, M.J., Lorensen, W.E., Schroeder, W., Chalana, V., Aylward, S. Metaxas, D., Whitaker, R., 2002. Engineering and Algorithm Design for an Image Processing API: A Technical Report on ITK - The Insight Toolkit. In: Westwood, J. (Ed.), Proceedings of Medicine Meets Virtual Reality. IOS Press, Amsterdam, pp. 586-592.

Zakrevskaya, M., 2014. Paleoecological reconstruction of the Ediacaran benthic macroscopic communities of the White Sea (Russia). Palaeogeogr. Palaeoclimatol. Palaeoecol. 410, 27-38.

Zhao, Z., Xing, Y., Ding, Q., Liu, G., Zhao, Y., Zhang, S., Meng, X., Yin, C., Ning, B., Han, P., 1988. The Sinian System of Hubei. China University of Geosciences Press, Wuhan.

Zhou, C., Xiao, S., Wang, W., Guan, C., Ouyang, Q., Chen, Z., 2017. The stratigraphic complexity of the middle Ediacaran carbon isotopic record in the Yangtze Gorges area, South China, and its implications for the age and chemostratigraphic significance of the Shuram excursion. Precambrian Res. 288, 23-38.

Zhu, R.X., Li, X.H., Hou, X.G., Pan, Y.X., Wang, F., Deng, C.L., He, H.Y., 2009. SIMS U-Pb zircon age of a tuff layer in the Meishucun section, Yunnan, southwest China: Constraint on the age of the Precambrian-Cambrian boundary. Sci. China Ser D (Earth Sciences) 39, 1105-1111. 